\title{
Profile and Regulation of Apolipoprotein E (ApoE) Expression in the CNS in Mice with Targeting of Green Fluorescent Protein Gene to the ApoE Locus
}

\author{
Qin Xu, ${ }^{1,2}$ Aubrey Bernardo, ${ }^{1}$ David Walker, ${ }^{1}$ Tiffany Kanegawa, ${ }^{1}$ Robert W. Mahley, ${ }^{1,2,4,5}$ and Yadong Huang ${ }^{1,2,3,4}$ \\ ${ }^{1}$ Gladstone Institute of Neurological Disease and ${ }^{2}$ Gladstone Institute of Cardiovascular Disease, San Francisco, California 94158, and Departments of \\ ${ }^{3}$ Neurology, ${ }^{4}$ Pathology, and ${ }^{5}$ Medicine, University of California, San Francisco, California 94143
}

\begin{abstract}
To study the profile and regulation of apolipoprotein $\mathrm{E}(\mathrm{apoE})$ expression in the CNS, we generated mice in which apoE expression can be detected in vivo with unprecedented sensitivity and resolution. cDNA encoding enhanced green fluorescent protein (EGFP) with a stop codon was inserted by gene targeting into the apoE gene locus $\left(\mathrm{EGFP}_{\mathrm{apoE}}\right)$ immediately after the translation initiation site. Insertion of EGFP into one apoE allele provides a real-time location marker of apoE expression in vivo; the remaining allele is sufficient to maintain normal cellular physiology. In heterozygous $\mathrm{EGFP}_{\text {apoE }}$ mice, EGFP was highly expressed in hepatocytes and peritoneal macrophages. EGFP was also expressed in brain astrocytes; however some astrocytes $(\sim 25 \%)$ expressed no EGFP, suggesting that a subset of these cells does not express apoE. EGFP was expressed in $<10 \%$ of microglia after kainic acid treatment, suggesting that microglia are not a major source of brain apoE. Although hippocampal neurons did not express EGFP under normal conditions, kainic acid treatment induced intense expression of EGFP in injured neurons, demonstrating apoE expression in neurons in response to excitotoxic injury. The neuronal expression was confirmed by in situ hybridization of mouse apoE mRNA and by anti-apoE immunostaining. Smooth muscle cells of large blood vessels and cells surrounding small vessels in the CNS also strongly expressed EGFP, as did cells in the choroid plexus. $\mathrm{EGFP}_{\text {apoE }}$ reporter mice will be useful for studying the regulation of apoE expression in the CNS and might provide insights into the diverse mechanisms of apoE4-related neurodegeneration.
\end{abstract}

Key words: apolipoprotein E; Alzheimer's disease; green fluorescent protein; excitotoxin; knock-in mice; gene regulation

\section{Introduction}

The $\varepsilon 4$ allele of the gene encoding apolipoprotein $\mathrm{E}$ (apoE) has been linked to late-onset familial and sporadic Alzheimer's disease (AD) and has a gene-dose effect on the risk and age of onset of the disease (Corder et al., 1993; Saunders et al., 1993; Roses, 1996; Tang et al., 1998; Romas et al., 2002). Individuals with two copies of the $\varepsilon 4$ allele have a $50-90 \%$ chance of developing AD by the age of 85 , compared with $\sim 45 \%$ for those with one allele (Corder et al., 1993; Farrer et al., 1997) and 20\% for the general population (Corder et al., 1993). ApoE is found in amyloid plaques and neurofibrillary tangles (two neuropathological hallmarks of $\mathrm{AD}$ ) and has been suggested to play important roles in the pathogenesis of these two lesions (Namba et al., 1991; Selkoe, 1991; Wisniewski and Frangione, 1992; Crowther, 1993; Strittmatter et al., 1993a; Roses, 1994; Holtzman et al., 2000; Irizarry et al., 2000; Tanzi and Bertram, 2001).

Received Dec. 21, 2005; revised March 7, 2006; accepted March 30, 2006.

This work was supported in part by National Institutes of Heath Grants P01 AG022074 and R01 HL37063 and a postdoctoral fellowship from the John Douglas French Alzheimer's Foundation. We thank Dr. Karl Weisgraber for critical reading of this manuscript, Karina Fantillo for manuscript preparation, Stephen Ordway and Gary Howard for editorial assistance, John C. W. Carroll and John Hull for graphics, and Chris Goodfellow for photography.

Correspondence should be addressed to Dr. Yadong Huang, Gladstone Institute of Neurological Disease, 1650 Owens Street, San Francisco, CA 94158. E-mail: yhuang@gladstone.ucsf.edu.

DOI:10.1523/JNEUROSCI.5476-05.2006

Copyright $\odot 2006$ Society for Neuroscience $\quad$ 0270-6474/06/264985-10\$15.00/0
Initially, apoE was thought to be synthesized in the brain only by astrocytes, oligodendrocytes, and ependymal layer cells (Boyles et al., 1985; Poirier et al., 1991). Although not all studies support the notion (Page et al., 1998; Nishio et al., 2003), increasing evidence suggests that under diverse pathophysiological conditions, CNS neurons also express apoE, albeit at lower levels than astrocytes (Diedrich et al., 1991; Han et al., 1994; Bao et al., 1996; Beffert and Poirier, 1996; Metzger et al., 1996; Xu et al., 1998, 1999a,b). The cellular origin of apoE appears to influence its effects on $\mathrm{AD}$ pathology (Huang et al., 2004; Huang, 2006). Astrocyte-derived apoE3 and apoE4 have different effects on the production, deposition, and clearance of $\mathrm{A} \beta$ (LaDu et al., 1994; Bales et al., 1999; Holtzman et al., 2000; Irizarry et al., 2000; Ji et al., 2001; Vincent and Smith, 2001; Ye et al., 2005) and on cholesterol efflux (Fagan et al., 1999; Gong et al., 2002). Neuron-derived apoE3 and apoE4 differ in their susceptibility to proteolysis (Huang et al., 2001; Harris et al., 2003; Brecht et al., 2004; Chang et al., 2005) and in their effects on mitochondrial function (Chang et al., 2005), tau phosphorylation (Tesseur et al., 2000a,b; Huang et al., 2001; Harris et al., 2003, 2004a; Brecht et al., 2004), lysosomal leakage (Ji et al., 2002), neurodegeneration (Buttini et al., 1999; Buttini et al., 2002), androgen receptor deficiency (Raber et al., 2002), and cognitive decline (Raber et al., 1998, 2000, 2002). Therefore, a better understanding of the profile and regulation of apoE expression in the CNS is important for unraveling the mechanisms underlying apoE4-related neurodegeneration. 
Regulation of apoE expression has been extensively studied in transfected cells (Reardon et al., 1986; Smith et al., 1988; García et al., 1996; Harris et al., 2004b) and in transgenic mice (Shachter et al., 1993; Simonet et al., 1993; Allan et al., 1995, 1997; Shih et al., 2000; Grehan et al., 2001a,b; Zheng et al., 2004) expressing apoE genomic or cDNA constructs. Although these systems have provided valuable information, practical considerations have limited systematic study of apoE expression. The high guanine and cytosine (GC) content of apoE coding sequences requires critical in situ hybridization conditions to limit nonspecific background signals while still providing acceptable sensitivity. Transfected cells are useful for mapping fine structures but have not yielded a fully accurate definition of any cell-specific regulation that reflects in vivo apoE expression. Transgenic models are hampered by variegated expression because of random integration of transgenes into the mouse genome. Enhancers and silencers of nearby endogenous genes can also interfere with transgene expression.

To avoid such limitations, we generated mice that express enhanced green fluorescent protein (EGFP) under control of the endogenous apoE gene promoter and enhancers $\left(\mathrm{EGFP}_{\mathrm{apoE}}\right)$, providing a realtime marker of in vivo apoE expression with unprecedented sensitivity and resolution. EGFP knock-in is a new approach to monitor gene expression in vivo (Aubert et al., 2003; Toyooka et al., 2003). Because it has no signal peptide, EGFP remains intracellular, and surrounding cells are not visible, avoiding confusion as to whether the immunostained apoE in certain cells is produced in situ or taken up through its receptors from the extracellular pool. Insertion of EGFP into one allele of the apoE gene provides a marker of apoE expression in vivo, and the remaining allele maintains normal lipid metabolism and cellular physiology and enables us to confirm the expression of apoE in various cells.

\section{Materials and Methods}

Reagents. Minimum essential medium, Opti-MEM, and fetal bovine serum were obtained from Invitrogen (Rockville, MD). ECL was obtained from Amersham Biosciences (Arlington, IL). Polyclonal rabbit antimouse apoE antibody was kindly provided by Dr. Karl Weisgraber (Gladstone Institutes, San Francisco, CA). Kainic acid and monoclonal anti$\alpha$-actin were obtained from Sigma (St. Louis, MO). Monoclonal anti-neuron-specific nuclear protein $(\mathrm{NeuN})$ and monoclonal antiCD11b were from Chemicon (Temecula, CA). Rabbit anti-GFAP was from Dako (Carpinteria, CA). Fluorescein isothiocyanate- and Texas Red-coupled anti-rabbit and anti-mouse were from Vector Laboratories (Burlingame, CA).

Preparation of EGFP knock-in vector. The gene-targeting vector (Fig. $1 A$ ) was constructed from a subclone of an $8.3 \mathrm{~kb} E c o \mathrm{R} 1$ fragment spanning exons 1-4 of mouse Apoe isolated from a 129/SvJae mouse genomic bacterial artificial chromosome library (Invitrogen, Carlsbad, CA) (Raffaï et al., 2001). An EGFP cDNA with a stop codon and a poly-A sequence
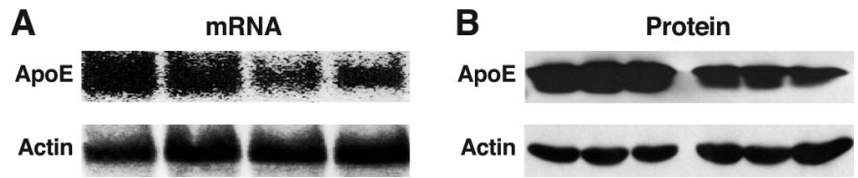

Figure 2. Heterozygous $\mathrm{EGFP}_{\text {apo }}$ mice express apoE at $\sim 50 \%$ of the level in wild-type mice. $\boldsymbol{A}$, Northern blotting analysis of apoE and actin mRNA in brains of wild-type and heterozygous $\mathrm{EGFP}_{\text {apoE }}$ mice at 5 months of age. $\boldsymbol{B}$, Western blotting analysis of apoE and actin in brains of wild-type and heterozygous $\mathrm{EGFP}_{\text {apoE }}$ mice at 5 months of age.

$(\sim 1 \mathrm{~kb})$ was inserted into the mouse apoE gene locus, immediately after the translation initiation site in exon 2. Insertion at this position is unlikely to affect the activities of the promoter and regulatory elements of the apoE gene. The insertion lengthens the apoE gene by only $\sim 1 \mathrm{~kb}$ toward the $3^{\prime}$-end, and the downstream enhancers are not position sensitive in regulating tissue/cell-specific apoE expression in transgenic mice (Shachter et al., 1993; Simonet et al., 1993; Allan et al., 1995, 1997; Shih et al., 2000; Grehan et al., 2001a,b; Zheng et al., 2004). LoxP sites upstream of EGFP and downstream of Neo allow cell-specific deletion of these genes by crossing EGFP mice with cell-specific Cre recombinase mice (Raffaï et al., 2001; Raffaï and Weisgraber, 2002).

Generation of EGFP knock-in mice. The EGFP-targeting vector was electroporated into embryonic stem (ES) cells (129/Svjae) as described 
A Liver Cells

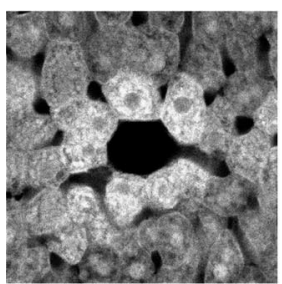

B

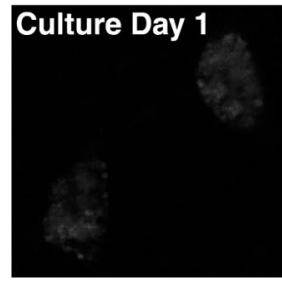

Peritoneal Macrophages

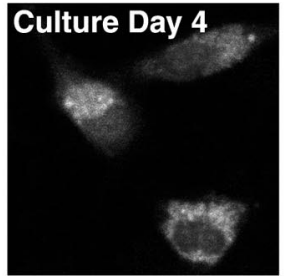

Figure 3. Expression of EGFP in hepatocytes and peritoneal macrophages in a heterozygous EGFP ${ }_{\text {apoE }}$ mouse at 2 months of age. $\boldsymbol{A}$, Expression of EGFP in hepatocytes as determined by confocal microscopy. $\boldsymbol{B}$, Peritoneal macrophages were cultured in vitro for 1 or $4 \mathrm{~d}$ and analyzed by confocal microscopy. Alternatively, after $4 \mathrm{~d}$ of culture, macrophages were incubated with acetylated LDL (AcLL; $100 \mu \mathrm{g} / \mathrm{ml}$ ) for $16 \mathrm{~h}$ and analyzed by confocal microscopy.
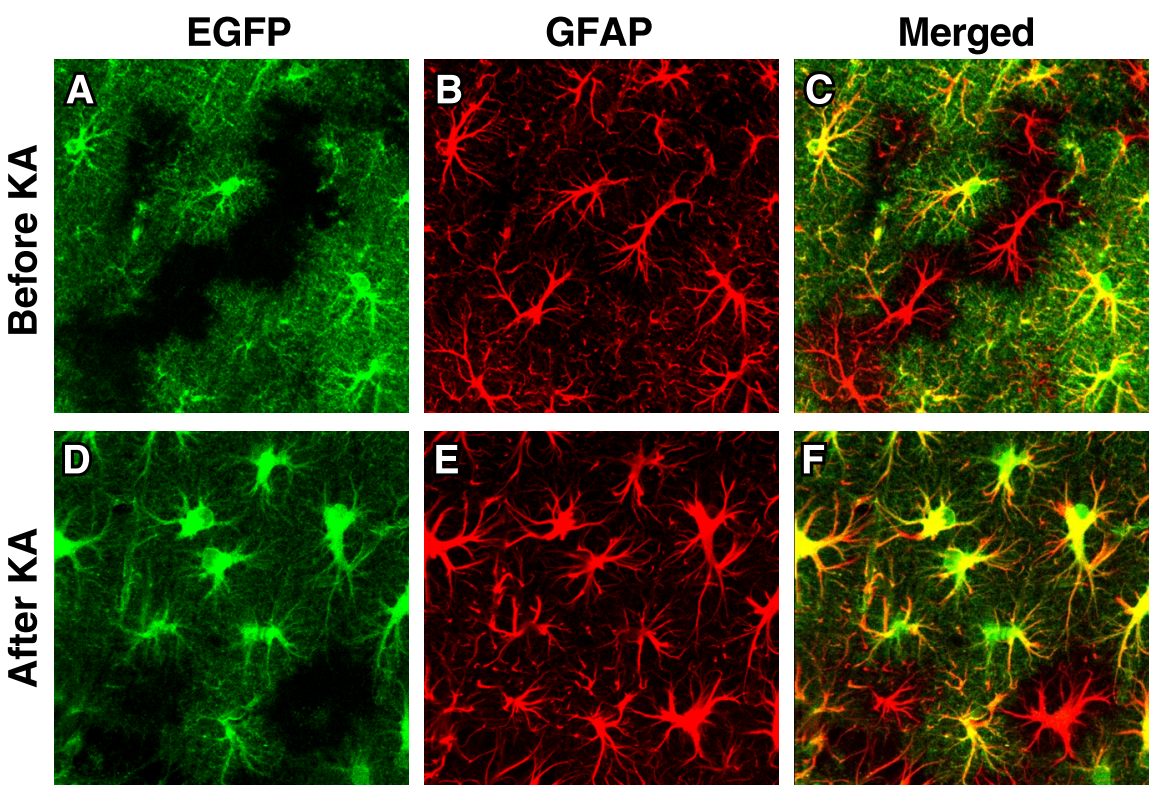

Figure 4. Expression of EGFP in hippocampal astrocytes in heterozygous EGFP ${ }_{\text {apoE }}$ mice at $4-6$ months of age before $(\boldsymbol{A}-\boldsymbol{C})$ and $6 \mathrm{~d}$ after ( $\boldsymbol{D}-\boldsymbol{F})$ kainic acid (KA) treatment $(25 \mathrm{mg} / \mathrm{kg}$ body weight). Astrocytes were identified by anti-GFAP immunostaining and confocal microscopy. In the merged image, yellow indicates colocalization of EGFP (green) and GFAP (red).

previously (Raffaï et al., 2001), and G418-resistant clones were selected and screened by PCR with primers covering Neo (forward) and 3' flanking sequence of mouse Apoe (reverse). The DNA sequence recognized by the reverse primer was not included in the vector (Fig. $1 A$ ). Therefore, a $1.5 \mathrm{~kb}$ fragment could only be amplified from the DNA of the targeted ES cells. Of 200 clones screened, 21 were positive (Fig. $1 B$ ).

The PCR-positive ES cell clones were also screened by Southern blotting. SacI-digested DNA was hybridized with a probe that detects fragments of $5.3 \mathrm{~kb}$ (targeted allele) and $3.3 \mathrm{~kb}$ (wild-type allele) in targeted ES cells $(+/-)$ but only a $3.3 \mathrm{~kb}$ fragment in wild-type cells (Fig. $1 \mathrm{~A}, \mathrm{C}$ ). Screening yielded 15 positive ES cell clones (Fig. $1 C$ ). Three were microinjected into C57BL/ 6 blastocysts in the Gladstone Blastocyst Core, yielding $>50$ chimeric mice harboring EGFP cDNA in the apoE locus. Six male chimeras ( $>90 \%$ brown fur) were crossed with C57BL/ 6 females to generate heterozygous $\mathrm{EGFP}_{\mathrm{apoE}}$ mice. Germline transmission resulted in heterozygous F1 EGFP ${ }_{\text {apoE }}$ mice (confirmed by PCR and Southern blotting analyses; data not shown) that are 50\% C57BL/6. Three additional crosses resulted in $\mathrm{F} 4$ mice that are $>93 \% \mathrm{C} 57 \mathrm{BL} / 6$. Heterozygous EGFP $_{\text {apoE }}$ mice were then bred to generate homozygotes to maintain the line. For the current study, we used heterozygous EGFP $_{\text {apoE }}$ mice, generated by crossing homozygous EGFP ${ }_{\text {apoE }}$ and wild-type C57BL/6 mice. Mice were weaned at $21 \mathrm{~d}$ of age, housed in a barrier facility at the Gladstone Animal Core with a $12 \mathrm{~h}$ light/dark cycle, and fed a chow diet containing 4.5\% fat (Ralston Purina, St. Louis, MO).

Northern blotting and quantitative analysis of apoE $m R N A$. Total RNA from brains of wild-type and heterozygous EGFP ${ }_{\mathrm{apoE}}$ mice was isolated

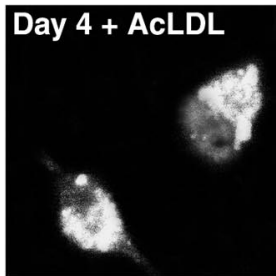

with Triazol (Invitrogen). Total RNA $(\sim 20 \mu \mathrm{g})$ was separated by electrophoresis in a $1 \%$ agarose gel containing $20 \%$ formaldehyde, transferred to Hybond membrane (Amersham Biosciences) and hybridized to a mouse apoE cDNA probe labeled with $\left[{ }^{32} \mathrm{P}\right] \mathrm{dCTP}$ in Ultrahyb solution (Ambion, Austin, TX) at $60^{\circ} \mathrm{C}$ overnight. The blot was washed in highstringency buffer (Ambion) at $68^{\circ} \mathrm{C}$ for $15 \mathrm{~min}$ (twice) and exposed to $\mathrm{x}$-ray film for 2-6 h. The blot was then washed with a Strip-EZ buffer (Ambion), rehybridized to a mouse $\beta$-actin probe as an internal loading control, and exposed to $\mathrm{x}$-ray film for $2-8 \mathrm{~h}$. The bands of apoE and $\beta$-actin mRNAs were scanned, and the ratios of apoE to $\beta$-actin were calculated.

Preparation of mouse brain tissues. Brains from wild-type or heterozygous $\mathrm{EGFP}_{\text {apoE }}$ mice were collected after a 2 min transcardial perfusion with PBS. One hemibrain from each mouse was homogenized and analyzed for apoE by Western blotting (Huang et al., 2001). In brief, brain tissues were homogenized in icecold lysis buffer (50 mu Tris/HCl, pH 8.0, 150 mм NaCl, $4 \%$ SDS, $1 \%$ Nonidet P-40, $1 \%$ sodium deoxycholate, and a mixture of protease and phosphatase inhibitors), placed in a TLA 100.3 rotor, and centrifuged at 35,000 rpm for $30 \mathrm{~min}$ at $4^{\circ} \mathrm{C}$ in an Optima TL ultracentrifuge (Beckman, Fullerton, CA).

Western blotting and quantitative analysis of apoE. The supernatant (solubilized protein) was subjected to SDS-PAGE and analyzed by Western blotting with a rabbit polyclonal antibody against mouse apoE or a monoclonal antibody against $\alpha$-actin. The bands of apoE and $\alpha$-actin from individual mice were scanned, and their intensities were calculated (Huang et al., 2001).

Immunohistochemistry. The other hemibrain from each mouse was fixed in 3\% paraformaldehyde, sectioned, and stained with anti-mouse apoE, anti-NeuN (neuron marker), anti-GFAP (astrocyte marker), anti- $\alpha$-actin (smooth muscle cell marker), and anti-CD11b (microglial marker) (Buttini et al., 1999; Huang et al., 2001). To block nonspecific reactions, all sections were incubated for $1 \mathrm{~h}$ in $10 \%$ normal serum from the species that produced the secondary antibodies (Jackson ImmunoResearch, West Grove, PA) in PBS or for 7 min in Superblock (Scytec, Logan, UT), followed by a $1 \mathrm{~h}$ incubation in PBS with primary antibodies. Sections were then washed three times in PBS and incubated for $1 \mathrm{~h}$ with the corresponding secondary antibodies coupled to Texas Red (Jackson ImmunoResearch). After three washes in PBS, the sections were mounted in VectaShield (Vector Laboratories) and examined for both green (EGFP) and red (other marker staining) channels with a Radiance 2000 laser-scanning confocal system (Bio-Rad, Hercules, CA) mounted on an Optiphot-2 microscope (Nikon, Tokyo, Japan). The images were processed with Photoshop (Adobe Systems, San Jose, CA).

Kainic acid injections. Kainic acid crosses the blood-brain barrier and induces excitotoxic CNS injury, particularly in the hippocampus and neocortex (Spinler and Cziraky, 1994; Masliah et al., 1997). At 4-6 months of age, heterozygous $\mathrm{EGFP}_{\mathrm{apoE}}$ mice were injected intraperitoneally with kainic acid (Sigma) dissolved in saline $(0.9 \%)$ at $25 \mathrm{mg} / \mathrm{kg}$ body weight in one dose, as described previously (Buttini et al., 1999). Within $\sim 15 \mathrm{~min}$, all mice developed seizures. Seizure activity was assessed as described previously (Schauwecker and Steward, 1997). The groups did not differ in the time from injection to seizure onset or in the incidence, intensity, or duration of seizures (data not shown). Mice were killed 1 or $6 \mathrm{~d}$ after the injection of kainic acid. 
In situ hybridization. RNA probe complementary to nucleotides $492-783$ of mouse apoE mRNA was labeled with $\left[{ }^{33} \mathrm{P}\right] \mathrm{UTP}$ with an RNA transcription kit (Stratagene, La Jolla, CA). The labeled probe was purified through Micro Bio-Spin 30 chromatography columns (Bio-Rad). In situ hybridization was performed as described previously (Grehan et al., 2001b). Briefly, brain paraffin sections $(7 \mu \mathrm{m})$ were incubated with $20 \mu \mathrm{g} / \mathrm{ml}$ proteinase $\mathrm{K}$ (Boehringer Mannheim, Indianapolis, IN) in $50 \mathrm{~mm}$ Tris- $\mathrm{HCl}, \mathrm{pH}$ 8.0, $5 \mathrm{~mm}$ EDTA, and $150 \mathrm{~mm}$ $\mathrm{NaCl}$ for $15 \mathrm{~min}$ at room temperature. Proteolytic activity was stopped by immersion for 10 $\min$ in $0.2 \%$ glycine in PBS. After fixation, acetylation, and dehydration, the sections were incubated for $14-18 \mathrm{~h}$ in a humidified chamber at $45^{\circ} \mathrm{C}$ with labeled probe in a buffer containing $50 \%$ formamide, $300 \mathrm{~mm} \mathrm{NaCl}, 20 \mathrm{~mm}$ Tris, $\mathrm{pH}$ 8.0, 5 mм EDTA, 0.2\% polyvinylpyrrolidone, $0.02 \%$ Ficoll, $0.02 \%$ bovine serum albumin, $10 \%$ dextran sulfate, $250 \mu \mathrm{g} / \mathrm{ml}$ sperm DNA, and $0.1 \mathrm{mg} / \mathrm{ml}$ tRNA. After two washes at room temperature in $2 \times$ SSC and $1.0 \mathrm{~mm}$ EDTA for $10 \mathrm{~min}$, the sections were immersed in $20 \mu \mathrm{g} / \mathrm{ml}$ ribonuclease (RNase) A (Sigma) in $500 \mathrm{~mm}$ $\mathrm{NaCl}$ and $10 \mathrm{~mm}$ Tris, $\mathrm{pH} 8.0$, and $10 \mathrm{U} / \mathrm{ml} \mathrm{T1}$ RNase (Boehringer Mannheim) for $1 \mathrm{~h}$ at $37^{\circ} \mathrm{C}$, washed at $60^{\circ} \mathrm{C}$ in six changes of $0.1 \times$ SSC with $1.0 \mathrm{~mm}$ EDTA for $4 \mathrm{~h}$, rinsed twice for $10 \mathrm{~min}$ each in $0.5 \times \mathrm{SSC}$, and dehydrated. For dark-field and bright-field microscopy, the slides were dipped in NTB2 nuclear track emulsion (Eastman Kodak, Rochester, NY), incubated at $4^{\circ} \mathrm{C}$ for 2-5 d, and developed with D19 developer (Eastman Kodak). The sections were then stained with hematoxylin and eosin (Fisher Scientific, Tustin, CA). After dehydration in a graded series of ethanol (80, 95, and 100\%), the slides were rinsed three times in xylene and overlaid with coverslips.

Statistical analysis. Results are reported as mean \pm SD. Differences were evaluated by a $t$ test.

\section{Results}

Heterozygous EGFP ${ }_{\text {apoE }}$ mice express both EGFP and apoE

As shown by Northern blotting, the average level of brain apoE mRNA in heterozygous EGFP apoE mice was $58 \%$ of that in wildtype mice (Fig. $2 \mathrm{~A}$ ), consistent with the expected inactivation of one apoE allele. The average level of apoE protein was $51 \%$ of wild-type, as shown by anti-apoE Western blotting (Fig. 2 B). Similar Western blotting results were obtained from liver and peritoneal macrophages of heterozygous $\mathrm{EGFP}_{\mathrm{apoE}}$ mice (data not shown).

\section{EGFP is expressed in hepatocytes and macrophages}

EGFP was expressed at high levels in liver cells (Fig. $3 A$ ), the primary source of apoE in both humans and mice. Peritoneal macrophages also expressed EGFP, and the expression was enhanced by cholesterol loading (Fig. 3B), as reported previously (Basu et al., 1981). Thus, in heterozygous EGFP ${ }_{\text {apoE }}$ mice, EGFP representing apoE was correctly expressed in hepatocytes and macrophages that normally express apoE.

\section{EGFP is expressed in many, but not all, CNS astrocytes}

EGFP was also expressed in CNS astrocytes and was confirmed by anti-GFAP immunofluorescent staining (Fig. 4A-C). Strikingly, EGFP revealed the full cell volume of astrocytes with very fine resolution of cellular processes, whereas anti-GFAP staining highlighted only large processes. Thus, EGFP is better than immunostaining for characterizing cell identity and morphology.
Interestingly, some GFAP-positive cells (26 $\pm 4 \%$ ) did not express EGFP, suggesting that a subclass of astrocytes might not express apoE, at least under normal conditions.

To determine whether brain insults can induce EGFPnegative astrocytes to express EGFP, we treated heterozygous EGFP $_{\text {apoE }}$ mice with kainic acid, which can activate astrocytes, induce gliosis, and increase apoE expression in animal models (Sperk et al., 1983). Hippocampal astrocytes were activated, as indicated by much stronger GFAP staining and enlarged cell bodies and branches; however, $17 \pm 3 \%$ of astrocytes still did not express EGFP (Fig. $4 D-F$ ).

\section{EGFP is expressed in $<10 \%$ of microglia}

\section{after kainic acid treatment}

EGFP was not expressed in CNS microglia as demonstrated by anti-CD11b, a microglial marker (Chen et al., 2005), immunofluorescent staining (Fig. 5A-C), suggesting that these cells do not express apoE under normal conditions. To determine whether brain insults can induce microglia to express EGFP, we treated heterozygous $\mathrm{EGFP}_{\text {apoE }}$ mice with kainic acid, which can activate microglia and induce gliosis (Sperk et al., 1983). Hippocampal microglia were activated by kainic acid treatment, as indicated by much stronger CD11b staining and enlarged cell bodies and branches; however, only $6 \pm 3 \%$ of microglia expressed EGFP (Fig. 5D-F).

\section{EGFP is expressed in hippocampal neurons}

\section{in response to exitotoxic injury}

EGFP was not expressed in hippocampal neurons in heterozygous $\mathrm{EGFP}_{\text {apoE }}$ mice, as demonstrated by staining for NeuN (a neuronal marker) (Fig. 6A) and GFAP (Fig. 6B). Thus, hippocampal neurons do not express apoE under normal conditions. However, kainic acid treatment induced intense expression of EGFP in injured hippocampal neurons (Fig. $6 C-G$ ). Importantly, both EGFP and apoE were only present in injured neurons in the treated mice (Fig. 7A, B,D,E). Neuronal expression of apoE was confirmed by in situ hybridization of mouse apoE mRNA in heterozygous $\mathrm{EGFP}_{\mathrm{apoE}}$ mice treated with kainic acid (Fig. 7F). 
EGFP/NeuN
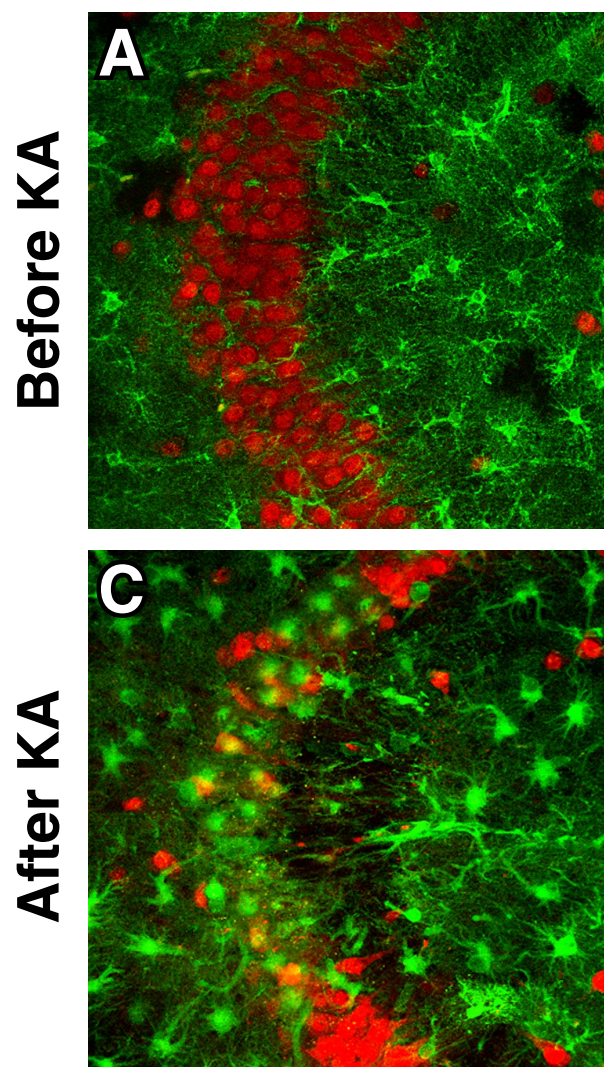

EGFP

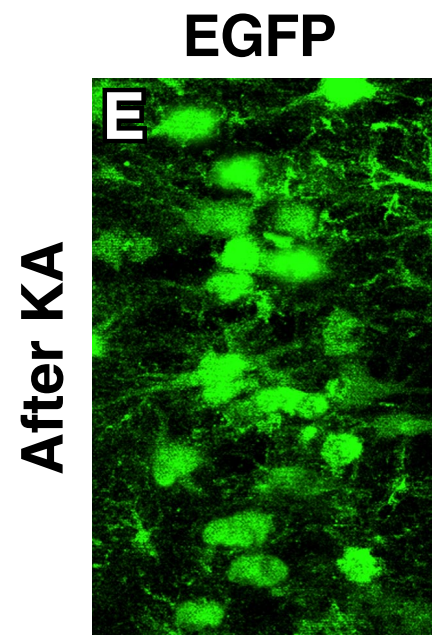

NeuN

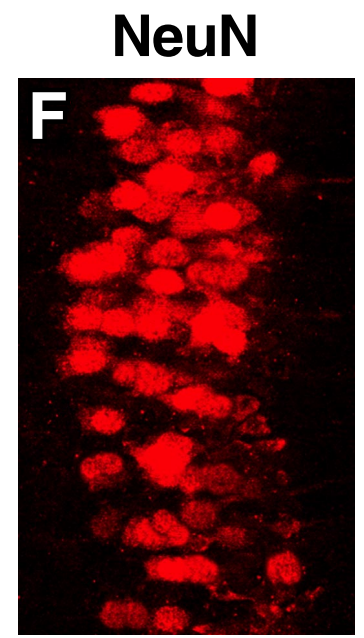

EGFP/GFAP
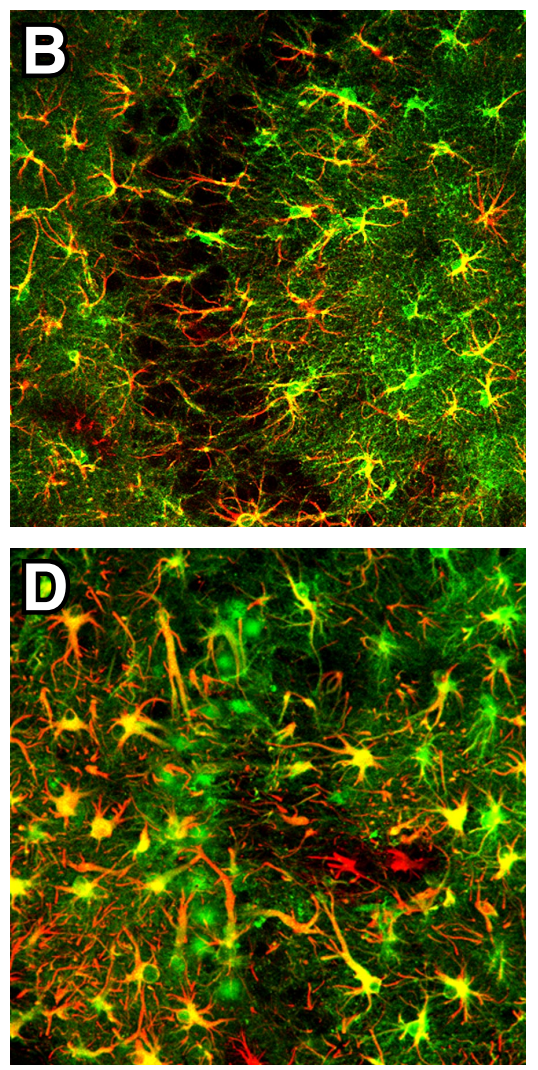

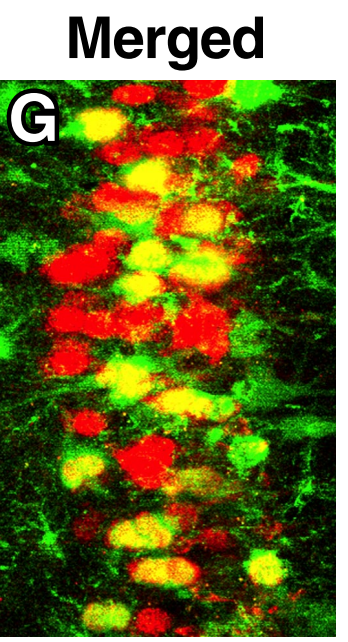

Figure 6. Hippocampal CA3 neurons express EGFP, representing apoE, in response to excitotoxic injury. Heterozygous 5 -month-old EGFP ${ }_{\text {apoE }}$ mice received peritoneal injections of kainic acid $(K A ; 25 \mathrm{mg} / \mathrm{kg})(\mathbf{C}-\mathbf{G})$, and the brains were collected $1 \mathrm{~d}$ $(\boldsymbol{E}-\boldsymbol{G})$ or $6 \mathrm{~d}(\boldsymbol{C}, \boldsymbol{D})$ later. Untreated age-matched heterozygous EGFP $_{\text {apoE }}$ mice served as controls $(\boldsymbol{A}, \boldsymbol{B})$. Confocal images of immunostained brain sections were collected for EGFP (green) and anti-NeuN (red), a neuronal marker, or anti-GFAP (red), an astrocytic marker. Images in $\boldsymbol{A}-\boldsymbol{D}$ and $\mathbf{G}$ are merged, and yellow indicates colocalization.

ApoE protein and mRNA were undetectable in hippocampal neurons in untreated mice (Fig. $7 B, C$ ), in which no neuronal injury was found, as determined by silver staining (Fig. 7A).

EGFP is expressed along CNS vessels and in the choroid plexus

EGFP was highly expressed along vessels in the CNS, as indicated by the close proximity or colocalization of EGFP with $\alpha$-actin (Fig. 8A-C), a smooth muscle cell marker (Deaton et al., 2005).
Interestingly, EGFP surrounded smooth muscle cells of small vessels in the hippocampus (Fig. $8 A$ ) and cortex (Fig. $8 B$ ) but colocalized with smooth muscle cells in large vessels in the cortex (Fig. 8C). In situ hybridization with a probe specific for mouse apoE demonstrated apoE mRNA in cells in or surrounding vessel walls (Fig. 8D). Anti-GFAP immunostaining indicated that the cells expressing EGFP along vessels were negative for GFAP, and thus were not astrocytes (Fig. $8 E, F$ ). EGFP was not expressed along veins in the CNS (data not shown). Cells of the choroid plexus also expressed high levels of EGFP (Fig. $9 A$ ) and contained apoE mRNA, as shown by in situ hybridization (Fig. 9B).

\section{Discussion}

This study of EGFP ${ }_{\text {apoE }}$ reporter mice provides insights into the profile and regulation of apoE expression in the CNS. Our findings demonstrate that neurons in the CNS produce apoE in response to injury. They also show that a subclass of astrocytes and most microglia do not express apoE, even after brain insults, and that many types of CNS cells in addition to astrocytes express apoE, including smooth muscle cells in larger blood vessels, cells surrounding small vessels, and cells of the choroid plexus. EGFP poE reporter mice will be invaluable for studying the regulation of apoE expression in the CNS at different developmental stages or in response to various brain insults and will likely provide additional insights into the roles of apoE in neurobiology and the diverse mechanisms of apoE4-related neurodegeneration.

Our study lays to rest a long-standing controversy concerning the neuronal expression of apoE. Some previous studies showed that at least some neurons express apoE (Diedrich et al., 1991; Poirier et al., 1991; Han et al., 1994; Bao et al., 1996; Metzger et al., 1996; Xu et al., 1996, 1999a,b; Dupont-Wallois et al., 1997; Boschert et al., 1999; Ferreira et al., 2000; Dekroon and Armati, 2001; Hartman et al., 2001; Aoki et al., 2003; Harris et al., 2003); others suggested that they do not (Page et al., 1998; Nishio et al., 2003). More recent studies suggest that neurons might not normally express apoE but do so in response to brain injuries, such as excitotoxic or ischemic injury (Boschert et al., 1999; Aoki et al., 2003). ApoE is also expressed in primary cultured human and rat CNS neurons (Dekroon and Armati, 2001) and in many human neuronal cell lines, including SY-5Y, Kelly, and NT2 cells (Poirier et al., 1991; Dupont-Wallois et al., 1997; Ferreira et al., 2000; Hartman et al., 2001).

In previous studies, anti-apoE immunostaining and in situ hybridization were used to define apoE expression in neurons. 
Both methods have been criticized for technical or data interpretation limitations. For example, anti-apoE immunostaining can not differentiate whether the apoE in neurons is generated in those cells or taken up from the astrocytesecreted pool. Likewise, in situ hybridization data are also questioned as false positive, because of the GC-rich nature of the apoE gene. In addition, in situ hybridization might also yield falsenegative results because of the poor sensitivity of the technique in detecting low-abundance mRNA in cells. Our EGFP $_{\text {apoE }}$ reporter mice avoid those limitations. Thus, our findings conclusively demonstrate that neurons express apoE in response to excitotoxic injury and support the notion that understanding how apoE expression is regulated in neurons is important for unraveling the mechanisms of apoE4-related neurodegenerative disorders.

Surprisingly, $\sim 20 \%$ of hippocampal and cortical astrocytes did not produce apoE, even in response to brain insults. We speculate that apoE-positive and apoEnegative astrocytes play different roles in brain development, neuronal injury and repair, and even some disease processes. Therefore, it would be interesting to know whether aging or neurodegenerative disorders such as $\mathrm{AD}$ alter the ratio of those two types of astrocytes.

It has been reported that cultured rat primary microglia and murine microglial cell line express apoE in vitro (Xu et al., 2000; Naidu et al., 2002; Saura et al., 2003; Mori et al., 2004). ApoE protein has also been found in activated microglia in $\mathrm{AD}$ brains and in lesioned olfactory bulb of mice by immunocytochemistry (Uchihara et al., 1995; Nathan et al., 2001). We demonstrated in the $\mathrm{EGFP}_{\mathrm{a}}$ poE reporter mice that microglia do not express apoE under normal conditions, and $<10 \%$ of microglia produce apoE in response to brain insults. Therefore, $\mathrm{mi}$ croglia are not a major source of brain apoE, at least in mice.

Smooth muscle cells of artery walls in peripheral tissues express apoE (Majack et al., 1988; Moore et al., 2004), and apoE has been detected in cells along vessels in the CNS by anti-apoE immunostaining (Boyles et al., 1985), but the source was unclear. We demonstrated that apoE is produced in smooth muscle cells in large vessels and in cells surrounding small vessels in the CNS. Clearly, those apoEexpressing cells surrounding small vessels are not astrocytes, because they are negative for anti-GFAP immunostaining. Although the cellular identity remains to be determined, apoE generated in these locations may be important in maintaining the integrity and normal function of the blood-brain barrier.
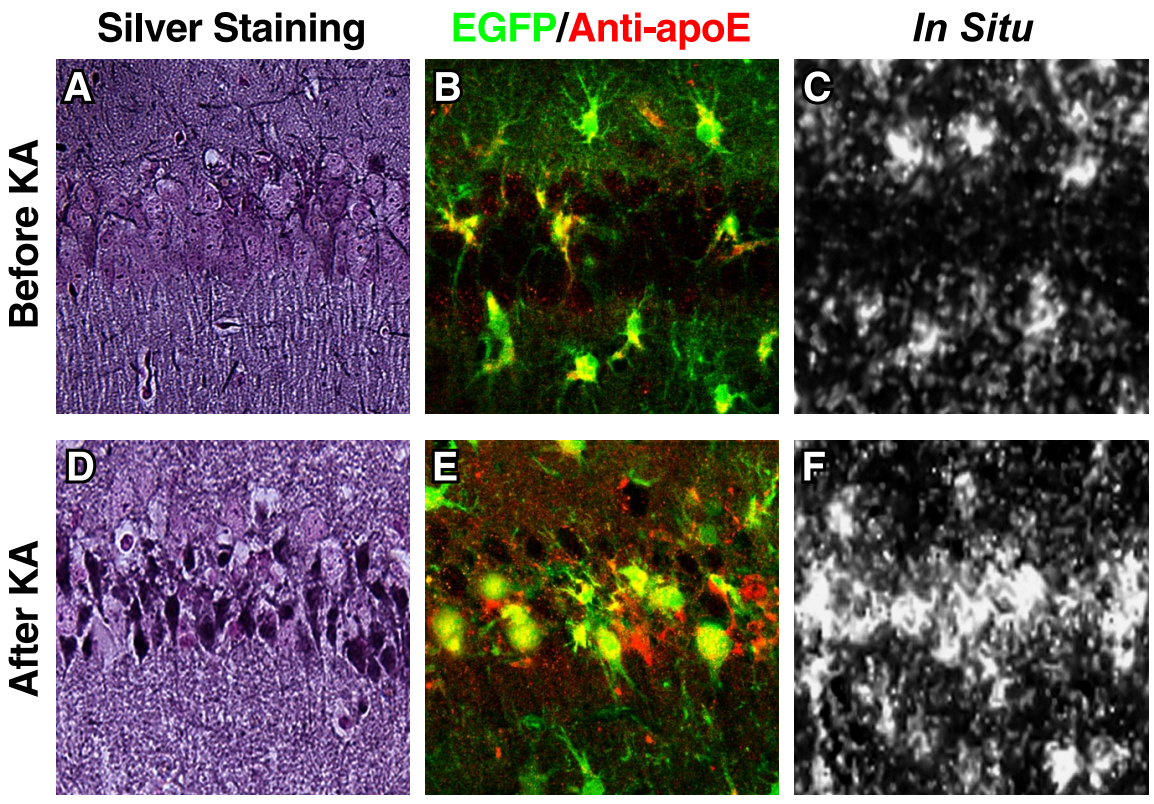

Figure 7. EGFP and apoE protein and mRNA are present only in injured hippocampal neurons in kainic acid-treated mice. Heterozygous 5-month-old EGFP ${ }_{\text {apoE }}$ mice received peritoneal injections of kainic acid $(K A ; 25 \mathrm{mg} / \mathrm{kg})(\boldsymbol{D}-\boldsymbol{F})$, and the brains were collected 6 d later. Untreated age-matched heterozygous EFPP $_{\text {apo }}$ mice served as controls $(\boldsymbol{A}-\boldsymbol{C})$. $\boldsymbol{A}, \boldsymbol{D}$, Gallyas silver staining of the hippocampal CA1 region. $\boldsymbol{B}, \boldsymbol{E}$, Merged confocal images of EGFP (green) and anti-apoE (red) in the CA1 region. $\boldsymbol{C}, \boldsymbol{F}$, In situ hybridization of mouse apoE mRNA in the CA1 region.

\section{EGFP/ $\alpha$-Actin}
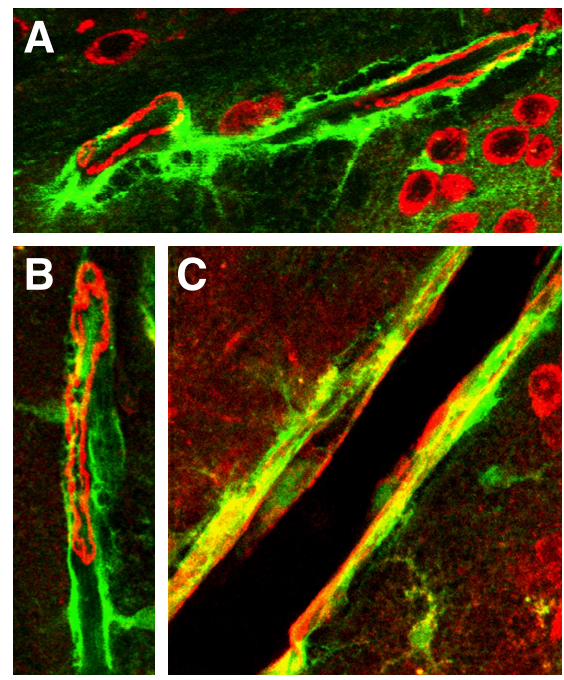

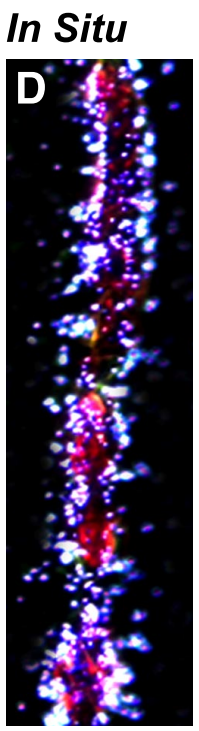

EGFP/GFAP
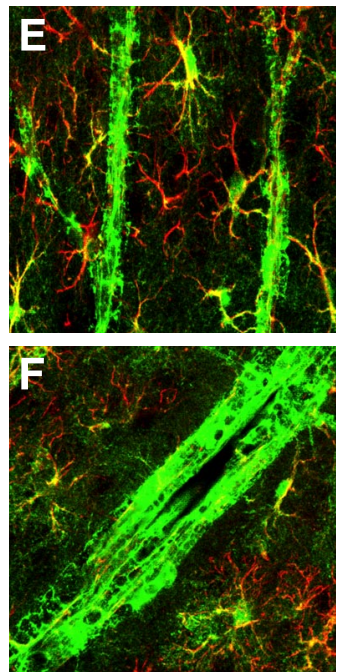

Figure 8. Expression of EGFP in smooth muscle cells in large blood vessels and cells surrounding small blood vessels in brains of heterozygous EGFP apoE mice. $\boldsymbol{A}$-C, Merged confocal images of EGFP (green) and anti- $\alpha$-actin (red), a smooth muscle cell marker, were collected from a 5-month-old heterozygous EGFP ${ }_{\text {apoE }}$ mouse. $\boldsymbol{A}$, Small blood vessels in the hippocampus. $\boldsymbol{B}$, A small blood vessel in the cortex. C, A large blood vessel in the cortex. D, In situ hybridization shows mouse apoE mRNA along the wall of a large blood vessel in the cortex. $\boldsymbol{E}, \boldsymbol{F}$, Merged confocal images of EGFP (green) and anti-GFAP (red), an astrocyte marker, were collected from a 5-month-old heterozygous EGFP $_{\text {apoE }}$ mouse.

In fact, apoE deficiency causes leakage of this structure (Fullerton et al., 2001; Methia et al., 2001). Furthermore, apoE has been found in lesions of cerebral amyloid angiopathy (CAA), and apoE4 is associated with increased severity of CAA in humans and amyloid protein precursor transgenic mice (Schmechel et al., 1993; Greenberg et al., 1995; Fryer et al., 2005).

It has been generally accepted that apoE in CAA is secreted by astrocytes (Fryer et al., 2003, 2005). ApoE4 might deliver more 
EGFP/GFAP

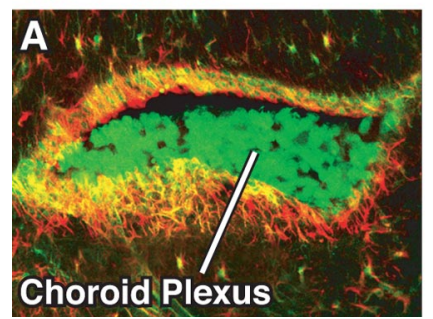

In Situ

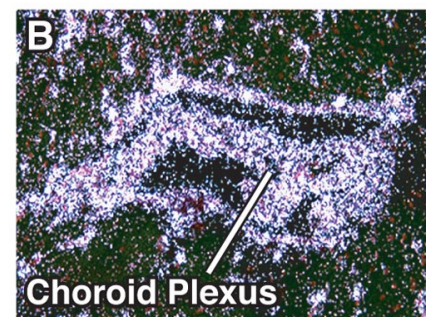

Figure 9. Expression of EGFP in choroid plexus cells of heterozygous EGFP apoE mice. $\boldsymbol{A}$, Merged confocal image of EGFP (green) and anti-GFAP (red) from a 5-month-old EGFP apoE mouse. $\boldsymbol{B}$, In situ hybridization revealed mouse apoE mRNA in the choroid plexus.

$\mathrm{A} \beta$ peptide than apoE3 from the brain parenchyma to vessel walls (Fryer et al., 2005). However, our observation that CNS cells in or around the vessel wall produce copious amounts of apoE raises the possibility that apoE4 generated in this location might retain more $\mathrm{A} \beta$ than apoE3, leading to more severe CAA in apoE4 carriers. In line with this hypothesis, CAA in $\mathrm{AD}$ brains occurs along the perivascular spaces of small blood vessels and between smooth muscle cells in large vessels (Weller et al., 1998). Interestingly, apoE was not expressed along veins in the CNS of the EGFP $_{\text {apoE }}$ mice, and CAA is seldom found along the veins in AD brains (Weller et al., 1998).

Finally, cells in the choroid plexus expressed high levels of apoE. The choroid plexus secretes CSF, expresses many receptors (e.g., apoE receptor-2), secretes numerous molecules (e.g., growth factors), transports nutrients from the blood to CSF, and clears brain metabolites (e.g., A $\beta$ peptides) (Kim et al., 1996; Martel et al., 1997; Serot et al., 2003; Crossgrove et al., 2005; Moir and Tanzi, 2005). ApoE levels in the CSF have not been reported in mice, but in humans are $5-15 \%$ of those in plasma (Pitas et al., 1987; Fukumoto et al., 2003). Our results suggest that the choroid plexus is the major source of apoE in CSF. Because the choroid plexus clears brain $A \beta$ peptides by transporting them from CSF to blood (Crossgrove et al., 2005) and because apoE isoforms interact differently with $\mathrm{A} \beta$ peptides (Strittmatter et al., 1993b; LaDu et al., 1994, 1995; Ma et al., 1994; Sanan et al., 1994; Wisniewski et al., 1994), apoE generated by the choroid plexus might affect $A \beta$ clearance in an isoform-specific manner. In fact, apoE knock-out mice have higher $A \beta$ levels in CSF than wild-type mice (DeMattos et al., 2004). Furthermore, the function of the choroid plexus declines with aging and in $\mathrm{AD}$ patients (Serot et al., 2003), which might lead to decreased clearance of $\mathrm{A} \beta$ peptides.

Clearly, apoE is expressed in different types of cells, in addition to astrocytes, in the CNS. We hypothesize that apoE from different cellular sources has distinct roles in both physiological and pathophysiological pathways, including the pathogenesis of AD (Huang et al., 2004; Huang, 2006). For example, apoE4 generated in injured neurons may be involved in mitochondrial dysfunction and neurofibrillary tangle formation (Huang et al., 2001; Harris et al., 2003; Brecht et al., 2004; Chang et al., 2005), apoE4 generated in astrocytes may be primarily responsible for amyloid plaque formation, apoE4 generated in or around blood vessels may be important for CAA formation, and apoE generated in the choroid plexus may participate in the clearance of $A \beta$ peptides. This hypothesis is supported by the early observation that apoE generated locally in the liver is much more efficient than that generated in the periphery in mediating the hepatic clearance of remnant lipoproteins (Mahley and Ji, 1999; Raffaï et al., 2003).

\section{References}

Allan CM, Walker D, Taylor JM (1995) Evolutionary duplication of a hepatic control region in the human apolipoprotein $\mathrm{E}$ gene locus. Identification of a second region that confers high level and liver-specific expression of the human apolipoprotein E gene in transgenic mice. J Biol Chem 270:26278-26281.

Allan CM, Taylor S, Taylor JM (1997) Two hepatic enhancers, HCR. 1 and HCR. 2, coordinate the liver expression of the entire human apolipoprotein E/C-I/C-IV/C-II gene cluster. J Biol Chem 272:29113-29119.

Aoki K, Uchihara T, Sanjo N, Nakamura A, Ikeda K, Tsuchiya K, Wakayama $\mathrm{Y}$ (2003) Increased expression of neuronal apolipoprotein $\mathrm{E}$ in human brain with cerebral infarction. Stroke 34:875-880.

Aubert J, Stavridis MP, Tweedie S, O’Reilly M, Vierlinger K, Li M, Ghazal P, Pratt T, Mason JO, Roy D, Smith A (2003) Screening for mammalian neural genes via fluorescence-activated cell sorter purification of neural precursors from Soxl-gfp knock-in mice. Proc Natl Acad Sci USA 100:11836-11841.

Bales KR, Verina T, Cummins DJ, Du Y, Dodel RC, Saura J, Fishman CE, DeLong CA, Piccardo P, Petegnief V, Ghetti B, Paul SM (1999) Apolipoprotein $\mathrm{E}$ is essential for amyloid deposition in the $A P P^{V 717 F}$ transgenic mouse model of Alzheimer's disease. Proc Natl Acad Sci USA 96:15233-15238.

Bao F, Arai H, Matsushita S, Higuchi S, Sasaki H (1996) Expression of apolipoprotein $\mathrm{E}$ in normal and diverse neurodegenerative disease brain. NeuroReport 7:1733-1739.

Basu SK, Brown MS, Ho YK, Havel RJ, Goldstein JL (1981) Mouse macrophages synthesize and secrete a protein resembling apolipoprotein E. Proc Natl Acad Sci USA 78:7545-7549.

Beffert U, Poirier J (1996) Apolipoprotein E, plaques, tangles and cholinergic dysfunction in Alzheimer's disease. Ann NY Acad Sci 777:166-174.

Boschert U, Merlo-Pich E, Higgins G, Roses AD, Catsicas S (1999) Apolipoprotein E expression by neurons surviving excitotoxic stress. Neurobiol Dis 6:508-514.

Boyles JK, Pitas RE, Wilson E, Mahley RW, Taylor JM (1985) Apolipoprotein $\mathrm{E}$ associated with astrocytic glia of the central nervous system and with nonmyelinating glia of the peripheral nervous system. J Clin Invest 76:1501-1513.

Brecht WJ, Harris FM, Chang S, Tesseur I, Yu G-Q, Xu Q, Fish JD, WyssCoray T, Buttini M, Mucke L, Mahley RW, Huang Y (2004) Neuronspecific apolipoprotein E4 proteolysis is associated with increased tau phosphorylation in brains of transgenic mice. J Neurosci 24:2527-2534.

Buttini M, Orth M, Bellosta S, Akeefe H, Pitas RE, Wyss-Coray T, Mucke L, Mahley RW (1999) Expression of human apolipoprotein E3 or E4 in the brains of $A$ poe $e^{-/}$mice: isoform-specific effects on neurodegeneration. J Neurosci 19:4867-4880.

Buttini M, Yu G-Q, Shockley K, Huang Y, Jones B, Masliah E, Mallory M, Yeo T, Longo FM, Mucke L (2002) Modulation of Alzheimer-like synaptic and cholinergic deficits in transgenic mice by human apolipoprotein $\mathrm{E}$ depends on isoform, aging, and overexpression of amyloid $\beta$ peptides but not on plaque formation. J Neurosci 22:10539-10548.

Chang S, Ma TR, Miranda RD, Balestra ME, Mahley RW, Huang Y (2005) Lipid- and receptor-binding regions of apolipoprotein E4 fragments act in concert to cause mitochondrial dysfunction and neurotoxicity. Proc Natl Acad Sci USA 102:18694-18699.

Chen J, Zhou Y, Mueller-Steiner S, Chen LF, Kwon H, Yi S, Mucke L, Gan L (2005) SIRT1 protects against microglia-dependent amyloid- $\beta$ toxicity through inhibiting NF- $\kappa$ B signaling. J Biol Chem 280:40364-40374.

Corder EH, Saunders AM, Strittmatter WJ, Schmechel DE, Gaskell PC, Small GW, Roses AD, Haines JL, Pericak-Vance MA (1993) Gene dose of apolipoprotein E type 4 allele and the risk of Alzheimer's disease in late onset families. Science 261:921-923.

Crossgrove JS, Li GJ, Zheng W (2005) The choroid plexus removes $\beta$-amyloid from brain cerebrospinal fluid. Exp Biol Med 230:771-776.

Crowther RA (1993) Tau protein and paired helical filaments of Alzheimer's disease. Curr Opin Struct Biol 3:202-206.

Deaton RA, Su C, Valencia TG, Grant SR (2005) Transforming growth factor- $\beta 1$-induced expression of smooth muscle marker genes involves activation of PKN and p38 MAPK. J Biol Chem 280:31172-31181.

Dekroon RM, Armati PJ (2001) Synthesis and processing of apolipoprotein $\mathrm{E}$ in human brain cultures. Glia 33:298-305. 
DeMattos RB, Cirrito JR, Parsadanian M, May PC, O’Dell MA, Taylor JW, Harmony JAK, Aronow BJ, Bales KR, Paul SM, Holtzman DM (2004) ApoE and clusterin cooperatively suppress $\mathrm{A} \beta$ levels and deposition: evidence that apoE regulates extracellular $\mathrm{A} \beta$ metabolism in vivo. Neuron 41:193-202.

Diedrich JF, Minnigan H, Carp RI, Whitaker JN, Race R, Frey Jr W, Haase AT (1991) Neuropathological changes in scrapie and Alzheimer's disease are associated with increased expression of apolipoprotein $\mathrm{E}$ and cathepsin D in astrocytes. J Virol 65:4759-4768.

Dupont-Wallois L, Soulié C, Sergeant N, Wavrant-de Wrieze N, ChartierHarlin M-C, Delacourte A, Caillet-Boudin M-L (1997) ApoE synthesis in human neuroblastoma cells. Neurobiol Dis 4:356-364.

Fagan KA, Fouty BW, Tyler RC, Morris Jr KG, Hepler LK, Sato K, LeCras TD, Abman SH, Weinberger HD, Huang PL, McMurtry IF, Rodman DM (1999) The pulmonary circulation of homozygous or heterozygous eNOS-null mice is hyperresponsive to mild hypoxia. J Clin Invest 103:291-299.

Farrer LA, Cupples LA, Haines JL, Hyman B, Kukull WA, Mayeux R, Myers RH, Pericak-Vance MA, Risch N, Van Duijn CM (1997) Effects of age, sex, and ethnicity on the association between apolipoprotein E genotype and Alzheimer disease. A meta-analysis. J Am Med Assoc 278:1349-1356.

Ferreira S, Dupire M-J, Delacourte A, Najib J, Caillet-Boudin M-L (2000) Synthesis and regulation of apolipoprotein E during the differentiation of human neuronal precursor NT2/D1 cells into postmitotic neurons. Exp Neurol 166:415-421.

Fryer JD, Taylor JW, DeMattos RB, Bales KR, Paul SM, Parsadanian M, Holtzman DM (2003) Apolipoprotein E markedly facilitates agedependent cerebral amyloid angiopathy and spontaneous hemorrhage in amyloid precursor protein transgenic mice. J Neurosci 23:7889-7896.

Fryer JD, Simmons K, Parsadanian M, Bales KR, Paul SM, Sullivan PM, Holtzman DM (2005) Human apolipoprotein E4 alters the amyloid$\beta 40: 42$ ratio and promotes the formation of cerebral amyloid angiopathy in an amyloid precursor protein transgenic model. J Neurosci 25:2803-2810.

Fukumoto H, Ingelsson M, Gårevik N, Wahlund L-O, Nukina N, Yaguchi Y, Shibata M, Hyman BT, Rebeck GW, Irizarry MC (2003) APOE $\varepsilon 3 / \varepsilon 4$ heterozygotes have an elevated proportion of apolipoprotein E4 in cerebrospinal fluid relative to plasma, independent of Alzheimer's disease diagnosis. Exp Neurol 183:249-253.

Fullerton SM, Shirman GA, Strittmatter WJ, Matthew WD (2001) Impairment of the blood-nerve and blood-brain barriers in apolipoprotein $\mathrm{E}$ knockout mice. Exp Neurol 169:13-22.

García MA, Vázquez J, Giménez C, Valdivieso F, Zafra F (1996) Transcription factor AP-2 regulates human apolipoprotein $\mathrm{E}$ gene expression in astrocytoma cells. J Neurosci 16:7550-7556.

Gong J-S, Kobayashi M, Hayashi H, Zou K, Sawamura N, Fujita SC, Yanagisawa K, Michikawa M (2002) Apolipoprotein E (apoE) isoformdependent lipid release from astrocytes prepared from human apoE3 and apoE4 knock-in mice. J Biol Chem 277:29919-29926.

Greenberg SM, Rebeck GW, Vonsattel JPG, Gomez-Isla T, Hyman BT (1995) Apolipoprotein E $\varepsilon 4$ and cerebral hemorrhage associated with amyloid angiopathy. Ann Neurol 38:254-259.

Grehan S, Allan C, Tse E, Walker D, Taylor JM (2001a) Expression of the apolipoprotein $\mathrm{E}$ gene in the skin is controlled by a unique downstream enhancer. J Invest Dermatol 116:77-84.

Grehan S, Tse E, Taylor JM (2001b) Two distal downstream enhancers direct expression of the human apolipoprotein $\mathrm{E}$ gene to astrocytes in the brain. J Neurosci 21:812-822.

Han S-H, Einstein G, Weisgraber KH, Strittmatter WJ, Saunders AM, Pericak-Vance M, Roses AD, Schmechel DE (1994) Apolipoprotein E is localized to the cytoplasm of human cortical neurons: a light and electron microscopic study. J Neuropathol Exp Neurol 53:535-544.

Harris FM, Brecht WJ, Xu Q, Tesseur I, Kekonius L, Wyss-Coray T, Fish JD, Masliah E, Hopkins PC, Scearce-Levie K, Weisgraber KH, Mucke L, Mahley RW, Huang Y (2003) Carboxyl-terminal-truncated apolipoprotein E4 causes Alzheimer's disease-like neurodegeneration and behavioral deficits in transgenic mice. Proc Natl Acad Sci USA 100:10966-10971.

Harris FM, Brecht WJ, Xu Q, Mahley RW, Huang Y (2004a) Increased tau phosphorylation in apolipoprotein E4 transgenic mice is associated with activation of extracellular signal-regulated kinase: modulation by zinc J Biol Chem 279:44795-44801.

Harris FM, Tesseur I, Brecht WJ, Xu Q, Mullendorff K, Chang S, Wyss-Coray T, Mahley RW, Huang Y (2004b) Astroglial regulation of apolipoprotein E expression in neuronal cells. Implications for Alzheimer's disease. J Biol Chem 279:3862-3868.

Hartman RE, Wozniak DF, Nardi A, Olney JW, Sartorius L, Holtzman DM (2001) Behavioral phenotyping of GFAP-apoE3 and -apoE4 transgenic mice: apoE4 mice show profound working memory impairments in the absence of Alzheimer's-like neuropathology. Exp Neurol 170:326-344.

Holtzman DM, Bales KR, Tenkova T, Fagan AM, Parsadanian M, Sartorius LJ, Mackey B, Olney J, McKeel D, Wozniak D, Paul SM (2000) Apolipoprotein $\mathrm{E}$ isoform-dependent amyloid deposition and neuritic degeneration in a mouse model of Alzheimer's disease. Proc Natl Acad Sci USA 97:2892-2897.

Huang Y (2006) Apolipoprotein E and Alzheimer disease. Neurology 66:S79-S85.

Huang Y, Liu XQ, Wyss-Coray T, Brecht WJ, Sanan DA, Mahley RW (2001) Apolipoprotein E fragments present in Alzheimer's disease brains induce neurofibrillary tangle-like intracellular inclusions in neurons. Proc Natl Acad Sci USA 98:8838-8843.

Huang Y, Weisgraber KH, Mucke L, Mahley RW (2004) Apolipoprotein E. Diversity of cellular origins, structural and biophysical properties, and effects in Alzheimer's disease. J Mol Neurosci 23:189-204.

Irizarry MC, Cheung BS, Rebeck GW, Paul SM, Bales KR, Hyman BT (2000) Apolipoprotein $\mathrm{E}$ affects the amount, form, and anatomical distribution of amyloid $\beta$-peptide deposition in homozygous $\mathrm{APP}^{\mathrm{V} 717 \mathrm{~F}}$ transgenic mice. Acta Neuropathol 100:451-458.

Ji Y, Permanne B, Sigurdsson EM, Holtzman DM, Wisniewski T (2001) Amyloid $\beta 40 / 42$ clearance across the blood-brain barrier following intraventricular injections in wild-type, apoE knock-out and human apoE3 or E4 expressing transgenic mice. J Alzheimers Dis 3:23-30.

Ji Z-S, Miranda RD, Newhouse YM, Weisgraber KH, Huang Y, Mahley RW (2002) Apolipoprotein E4 potentiates amyloid $\beta$ peptide-induced lysosomal leakage and apoptosis in neuronal cells. J Biol Chem 277:21821-21828.

Kim D-H, Iijima H, Goto K, Sakai J, Ishii H, Kim H-J, Suzuki H, Kondo H, Saeki S, Yamamoto T (1996) Human apolipoprotein E receptor 2. A novel lipoprotein receptor of the low density lipoprotein receptor family predominantly expressed in brain. J Biol Chem 271:8373-8380.

LaDu MJ, Falduto MT, Manelli AM, Reardon CA, Getz GS, Frail DE (1994) Isoform-specific binding of apolipoprotein $\mathrm{E}$ to $\beta$-amyloid. J Biol Chem 269:23403-23406.

LaDu MJ, Pederson TM, Frail DE, Reardon CA, Getz GS, Falduto MT (1995) Purification of apolipoprotein E attenuates isoform-specific binding to $\beta$-amyloid. J Biol Chem 270:9039-9042.

Ma J, Yee A, Brewer Jr HB, Das S, Potter H (1994) Amyloid-associated proteins $\alpha_{1}$-antichymotrypsin and apolipoprotein E promote assembly of Alzheimer $\beta$-protein into filaments. Nature 372:92-94.

Mahley RW, Ji Z-S (1999) Remnant lipoprotein metabolism: key pathways involving cell-surface heparan sulfate proteoglycans and apolipoprotein E. J Lipid Res 40:1-16.

Majack RA, Castle CK, Goodman LV, Weisgraber KH, Mahley RW, Shooter EM, Gebicke-Haerter PJ (1988) Expression of apolipoprotein E by cultured vascular smooth muscle cells is controlled by growth state. J Cell Biol 107:1207-1213.

Martel CL, Mackic JB, Matsubara E, Governale S, Miguel C, Miao W, McComb JG, Frangione B, Ghiso J, Zlokovic BV (1997) Isoform-specific effects of apolipoproteins E2, E3, and E4 on cerebral capillary sequestration and blood-brain barrier transport of circulating Alzheimer's amyloid $\beta$. J Neurochem 69:1995-2004.

Masliah E, Westland CE, Rockenstein EM, Abraham CR, Mallory M, Veinberg I, Sheldon E, Mucke L (1997) Amyloid precursor proteins protect neurons of transgenic mice against acute and chronic excitotoxic injuries in vivo. Neuroscience 78:135-146.

Methia N, André P, Hafezi-Moghadam A, Economopoulos M, Thomas KL, Wagner DD (2001) ApoE deficiency compromises the blood brain barrier especially after injury. Mol Med 7:810-815.

Metzger RE, LaDu MJ, Pan JB, Getz GS, Frail DE, Falduto MT (1996) Neurons of the human frontal cortex display apolipoprotein $\mathrm{E}$ immunoreactivity: implications for Alzheimer's disease. J Neuropathol Exp Neurol 55:372-380. 
Moir RD, Tanzi RE (2005) LRP-mediated clearance of $A \beta$ is inhibited by KPI-containing isoforms of APP. Curr Alzheimer Res 2:269-273.

Moore ZWQ, Zhu B, Kuhel DG, Hui DY (2004) Vascular apolipoprotein E expression and recruitment from circulation to modulate smooth muscle cell response to endothelial denudation. Am J Pathol 164:2109-2116.

Mori K, Yokoyama A, Yang L, Yang L, Maeda N, Mitsuda N, Tanaka J (2004) L-Serine-mediated release of apolipoprotein $\mathrm{E}$ and lipids from microglial cells. Exp Neurol 185:220-231.

Naidu A, Xu Q, Catalano R, Cordell B (2002) Secretion of apolipoprotein E by brain glia requires protein prenylation and is suppressed by statins. Brain Res 958:100-111.

Namba Y, Tomonaga M, Kawasaki H, Otomo E, Ikeda K (1991) Apolipoprotein E immunoreactivity in cerebral amyloid deposits and neurofibrillary tangles in Alzheimer's disease and kuru plaque amyloid in Creutzfeldt-Jakob disease. Brain Res 541:163-166.

Nathan BP, Nisar R, Randall S, Short J, Sherrow M, Wong GK, Struble RG (2001) Apolipoprotein E is upregulated in olfactory bulb glia following peripheral receptor lesion in mice. Exp Neurol 172:128-136.

Nishio M, Kohmura E, Yuguchi T, Nakajima Y, Fujinaka T, Akiyama C, Iwata A, Yoshimine T (2003) Neuronal apolipoprotein E is not synthesized in neuron after focal ischemia in rat brain. Neurol Res 25:390-394.

Page KJ, Hollister RD, Hyman BT (1998) Dissociation of apolipoprotein and apolipoprotein receptor response to lesion in the rat brain: An in situ hybridization study. Neuroscience 85:1161-1171.

Pitas RE, Boyles JK, Lee SH, Hui D, Weisgraber KH (1987) Lipoproteins and their receptors in the central nervous system. Characterization of the lipoproteins in cerebrospinal fluid and identification of apolipoprotein $\mathrm{B}, \mathrm{E}(\mathrm{LDL})$ receptors in the brain. J Biol Chem 262:14352-14360.

Poirier J, Hess M, May PC, Finch CE (1991) Astrocytic apolipoprotein E mRNA and GFAP mRNA in hippocampus after entorhinal cortex lesioning. Mol Brain Res 11:97-106.

Raber J, Wong D, Buttini M, Orth M, Bellosta S, Pitas RE, Mahley RW, Mucke L (1998) Isoform-specific effects of human apolipoprotein E on brain function revealed in ApoE knockout mice: increased susceptibility of females. Proc Natl Acad Sci USA 95:10914-10919.

Raber J, Wong D, Yu G-Q, Buttini M, Mahley RW, Pitas RE, Mucke L (2000) Apolipoprotein E and cognitive performance. Nature 404:352-354.

Raber J, Bongers G, LeFevour A, Buttini M, Mucke L (2002) Androgens protect against apolipoprotein E4-induced cognitive deficits. J Neurosci 22:5204-5209.

Raffaï RL, Weisgraber KH (2002) Hypomorphic apolipoprotein E mice. A new model of conditional gene repair to examine apolipoprotein E-mediated metabolism. J Biol Chem 277:11064-11068.

Raffaï RL, Dong L-M, Farese Jr RV, Weisgraber KH (2001) Introduction of human apolipoprotein E4 "domain interaction" into mouse apolipoprotein E. Proc Natl Acad Sci USA 98:11587-11591.

Raffaï RL, Hasty AH, Wang Y, Mettler SE, Sanan DA, Linton MF, Fazio S, Weisgraber KH (2003) Hepatocyte-derived apoE is more effective than non-hepatocyte-derived apoE in remnant lipoprotein clearance. J Biol Chem 278:11670-11675.

Reardon CA, Lau Y-F, Paik Y-K, Weisgraber KH, Mahley RW, Taylor JM (1986) Expression of the human apolipoprotein E gene in cultured mammalian cells. J Biol Chem 261:9858-9864.

Romas SN, Santana V, Williamson J, Ciappa A, Lee JH, Rondon HZ, Estevez P, Lantigua R, Medrano M, Torres M, Stern Y, Tycko B, Mayeux R (2002) Familial Alzheimer disease among Caribbean Hispanics. A reexamination of its association with APOE. Arch Neurol 59:87-91.

Roses AD (1994) The Alzheimer diseases. Curr Neurol 14:111-141.

Roses AD (1996) Apolipoprotein E alleles as risk factors in Alzheimer's disease. Annu Rev Med 47:387-400.

Sanan DA, Weisgraber KH, Russell SJ, Mahley RW, Huang D, Saunders A, Schmechel D, Wisniewski T, Frangione B, Roses AD, Strittmatter WJ (1994) Apolipoprotein E associates with $\beta$ amyloid peptide of Alzheimer's disease to form novel monofibrils. Isoform apoE4 associates more efficiently than apoE3. J Clin Invest 94:860-869.

Saunders AM, Strittmatter WJ, Schmechel D, St George-Hyslop PH, PericakVance MA, Joo SH, Rosi BL, Gusella JF, Crapper-MacLachlan DR, Alberts MJ, Hulette C, Crain B, Goldgaber D, Roses AD (1993) Association of apolipoprotein E allele $\varepsilon 4$ with late-onset familial and sporadic Alzheimer's disease. Neurology 43:1467-1472.
Saura J, Petegnief V, Wu X, Liang Y, Paul SM (2003) Microglial apolipoprotein $\mathrm{E}$ and astroglial apolipoprotein $\mathrm{J}$ expression in vitro: opposite effects of lipopolysaccharide. J Neurochem 85:1455-1467.

Schauwecker PE, Steward O (1997) Genetic determinants of susceptibility to excitotoxic cell death: implications for gene targeting approaches. Proc Natl Acad Sci USA 94:4103-4108.

Schmechel DE, Saunders AM, Strittmatter WJ, Crain BJ, Hulette CM, Joo SH, Pericak-Vance MA, Goldgaber D, Roses AD (1993) Increased amyloid $\beta$-peptide deposition in cerebral cortex as a consequence of apolipoprotein E genotype in late-onset Alzheimer disease. Proc Natl Acad Sci USA 90:9649-9653.

Selkoe DJ (1991) The molecular pathology of Alzheimer's disease. Neuron 6:487-498.

Serot J-M, Béné M-C, Faure GC (2003) Choroid plexus, aging of the brain, and Alzheimer's disease. Front Biosci 8:s515-s521.

Shachter NS, Zhu Y, Walsh A, Breslow JL, Smith JD (1993) Localization of a liver-specific enhancer in the apolipoprotein E/C-I/C-II gene locus. J Lipid Res 34:1699-1707.

Shih S-J, Allan C, Grehan S, Tse E, Moran C, Taylor JM (2000) Duplicated downstream enhancers control expression of the human apolipoprotein $\mathrm{E}$ gene in macrophages and adipose tissue. J Biol Chem 275:31567-31572.

Simonet WS, Bucay N, Lauer SJ, Taylor JM (1993) A far-downstream hepatocyte-specific control region directs expression of the linked human apolipoprotein E and C-I genes in transgenic mice. J Biol Chem 268:8221-8229.

Smith JD, Melián A, Leff T, Breslow JL (1988) Expression of the human apolipoprotein $\mathrm{E}$ gene is regulated by multiple positive and negative elements. J Biol Chem 263:8300-8308.

Sperk G, Lassmann H, Baran H, Kish SJ, Seitelberger F, Hornykiewicz O (1983) Kainic acid induced seizures: neurochemical and histopathological changes. Neuroscience 10:1301-1315.

Spinler SA, Cziraky MJ (1994) Lipoprotein(a): physiologic function, association with atherosclerosis, and effects of lipid-lowering drug therapy. Ann Pharmacother 28:343-351.

Strittmatter WJ, Saunders AM, Schmechel D, Pericak-Vance M, Enghild J, Salvesen GS, Roses AD (1993a) Apolipoprotein E: high-avidity binding to $\beta$-amyloid and increased frequency of type 4 allele in late-onset familial Alzheimer disease. Proc Natl Acad Sci USA 90:1977-1981.

Strittmatter WJ, Weisgraber KH, Huang DY, Dong L-M, Salvesen GS, Pericak-Vance M, Schmechel D, Saunders AM, Goldgaber D, Roses AD (1993b) Binding of human apolipoprotein $\mathrm{E}$ to synthetic amyloid $\beta$ peptide: isoform-specific effects and implications for late-onset Alzheimer disease. Proc Natl Acad Sci USA 90:8098-8102.

Tang M-X, Stern Y, Marder K, Bell K, Gurland B, Lantigua R, Andrews H, Feng L, Tycko B, Mayeux R (1998) The APOE- 84 allele and the risk of Alzheimer disease among African Americans, whites, and Hispanics. J Am Med Assoc 279:751-755.

Tanzi RE, Bertram L (2001) New frontiers in Alzheimer's disease genetics. Neuron 32:181-184.

Tesseur I, Van Dorpe J, Bruynseels K, Bronfman F, Sciot R, Van Lommel A, Van Leuven F (2000a) Prominent axonopathy and disruption of axonal transport in transgenic mice expressing human apolipoprotein E4 in neurons of brain and spinal cord. Am J Pathol 157:1495-1510.

Tesseur I, Van Dorpe J, Spittaels K, Van den Haute C, Moechars D, Van Leuven F (2000b) Expression of human apolipoprotein E4 in neurons causes hyperphosphorylation of protein tau in the brains of transgenic mice. Am J Pathol 156:951-964.

Toyooka Y, Tsunekawa N, Akasu R, Noce T (2003) Embryonic stem cells can form germ cells in vitro. Proc Natl Acad Sci USA 100:11457-11462.

Uchihara T, Duyckaerts C, He Y, Kobayashi K, Seilhean D, Amouyel P, Hauw J-J (1995) ApoE immunoreactivity and microglial cells in Alzheimer's disease brain. Neurosci Lett 195:5-8.

Vincent B, Smith JD (2001) Astrocytes down-regulate neuronal $\beta$-amyloid precursor protein expression and modify its processing in an apolipoprotein E isoform-specific manner. Eur J Neurosci 14:256-266.

Weller RO, Massey A, Newman TA, Hutchings M, Kuo Y-M, Roher AE (1998) Cerebral amyloid angiopathy. Am J Pathol 153:725-733.

Wisniewski T, Frangione B (1992) Apolipoprotein E: a pathological chaperone protein in patients with cerebral and systemic amyloid. Neurosci Lett 135:235-238.

Wisniewski T, Castaño EM, Golabek A, Vogel T, Frangione B (1994) Accel- 
eration of Alzheimer's fibril formation by apolipoprotein $\mathrm{E}$ in vitro. Am J Pathol 145:1030-1035.

Xu P-T, Schmechel D, Rothrock-Christian T, Burkhart DS, Qiu H-L, Popko B, Sullivan P, Maeda N, Saunders AM, Roses AD, Gilbert JR (1996) Human apolipoprotein E2, E3, and E4 isoform-specific transgenic mice: human-like pattern of glial and neuronal immunoreactivity in central nervous system not observed in wild-type mice. Neurobiol Dis 3:229-245.

Xu P-T, Gilbert JR, Qiu H-L, Rothrock-Christian T, Settles DL, Roses AD, Schmechel DE (1998) Regionally specific neuronal expression of human APOE gene in transgenic mice. Neurosci Lett 246:65-68.

Xu P-T, Gilbert JR, Qiu H-L, Ervin J, Rothrock-Christian TR, Hulette C, Schmechel DE (1999a) Specific regional transcription of apolipoprotein $\mathrm{E}$ in human brain neurons. Am J Pathol 154:601-611.

Xu P-T, Schmechel D, Qiu H-L, Herbstreith M, Rothrock-Christian T, Eyster
M, Roses AD, Gilbert JR (1999b) Sialylated human apolipoprotein E $\left(a_{0} E_{s}\right)$ is preferentially associated with neuron-enriched cultures from APOE transgenic mice. Neurobiol Dis 6:63-75.

Xu Q, Li Y, Cyras C, Sanan DA, Cordell B (2000) Isolation and characterization of apolipoproteins from murine microglia. Identification of a low density lipoprotein-like apolipoprotein J-rich but E-poor spherical particle. J Biol Chem 275:31770-31777.

Ye S, Huang Y, Müllendorff K, Dong L, Giedt G, Meng EC, Cohen FE, Kuntz ID, Weisgraber KH, Mahley RW (2005) Apolipoprotein (apo) E4 enhances amyloid $\beta$ peptide production in cultured neuronal cells: apoE structure as a potential therapeutic target. Proc Natl Acad Sci USA 102:18700-18705.

Zheng P, Pennacchio LA, Le Goff W, Rubin EM, Smith JD (2004) Identification of a novel enhancer of brain expression near the apoE gene cluster by comparative genomics. Biochim Biophys Acta 1676:41-50. 